members of Advanced Level (General Certificate of Education) standard have studied the history and techniques. The most interesting project has been in connexion with a project for sixth-formers. Two sixth-formers of the Salesian College, Battersea, with no previous knowledge of radio astronomy, were set a three-part project. The first part dealt with fundamentals, the second part with a simple practical project and the third was a dissertation on the two parts of the project followed by an oral examination. The boys were given only the minimum of information, and at the time of writing the first part of the work had been completed. The indications are that their work will throw considerable light on the value of project work with oral examinations being included among the methods of university selection.

Although the Radio-Electronics Section cannot possibly compete with the professional radio astronomers, it is clear that there are a number of small but valuable research projects which they can perform. The time taken for the completion of the project is admittedly long.

The other asset of the educational policy of the Section is that it has enabled a number of people to come into contact with the practice of the science and others to gain their first contact with this new science. These are important factors in a science where professionals are few and far between.
The financial support given by the Carnegie Trust, the Council of the British Astronomical Association and the encouragement of the professional radio astronomers, and of the Department of Telecommunication, Norwood Technical College, seem to justify the aims which the Section has set itself. These are aims which undertake a new responsibility for amateur science ; the provision of a new type of link between the scientist and the public : the provision of a liberalization for science in its increasing specializationa liberalization that reminds people that in all the complexity of modern technological thinking it is still possible for an outsider in his own time and at his own inclination to come to grips with the mysteries of the universe.

J. HEYWOOD

1 Heywood, J., Proc. Roy. Soc., A, 248, 82 (1958).

"Memoir of the British Astronomical Association on "Earth Satellites" (to be published Feb. 1961).

a Taylor, G. E., J. Brit. Astron. Assoc., 69, 121 (1959).

- Lovell, A. C. B. (Kelvin Lecture), Proc. Inst. Elect. Eng., 108, B. 711 (1956).

5 Husband, H. C., Proc. Inst. Civil Eng., 9, 65 (1958).

- Christiansen, W. N., Prac. Inst. Rad. Eng., 20, 519 (1959).

7 Heywood, J., J. Brit. Astron. Assoc. Proc., 70, 116 (1960); J. Jr Inst. Eng., Lond., 70, 209 (1960).

- Carr, T. D., J. Brit. Astron. As8oc., 70, 185 (1960)

- Hewish, A., Mon. Not. Roy. Astron. Soc., 118, 534 (1958).

10 Gardner, F. F., and Shain, C. A., Austral. J. Phy8., 11, 55 (1958). 1 Smith, A. G., et al., Nature, 187, 568 (1960).

12 Heywood, J., J. Brit. Astron. Assoc. (Sect. Rep.), 69, 26 (1958).

\title{
THE TWENTY-FIRST INTERNATIONAL GEOLOGICAL CONGRESS
}

$\mathrm{T}$ HE twenty-first International Geological Congress was held this year in the Nordic countries, with excursions in Denmark, Finland, Tceland, Norway and Sweden, and with meetings in Copenhagen during August 15-25. The usual excursions were in three groups : those preceding the actual meetings in Copenhagen; one-day excursions during the meetings; and longer excursions afterwards, some of which ended in mid-September. The number of geologists participating was about 2,500, coming from about a hundred various countries.

Although the possibility had been touched on in 1952, in Algiers, it was not until the 1956 meeting in Mexico that the invitation to geologists of the world to hold the Congress in the Scandinavian countries in 1960 was brought forward. After the invitation had been accepted, an organizing committee of the Congress was appointed by the geologists of the five countries. Its composition was as follows : Denmark, Arne Noe-Nygaard, Theodor Sorgenfrei and Christian Poulsen; Finland, A. Laitakari, P. Haapala, V. Marmo and $H$. Ignatius; Iceland, S. Thorarinsson, T. Tryggvason and G. Kjartansson; Norway, $O$. Holtedahl, T. F. W. Barth and J. A. Dons ; Sweden, K. A. Lindbergson, N. H. Magnusson, F. E. Wickmann and E. Fromm. During the preparation period the organizing committee met from time to time in the different countries ; at shorter intervals executive secretaries from each country came together (Dons, Fromm, Ignatius and Sorgenfrei). It does not minimize the efforts of the members of the organizing committee as a whole that the splendid work carried out by Dr. Sorgenfrei, on whose shoulders the heaviest burdens fell, is specifically underlined.
Of the excursions primarily offered, a few had to be cancelled for various reasons. The total number of guide booklets worked out was 42 , amounting to more than 1,500 pages. As is usually the case, a considerable number of pre-sessional excursions were repeated as post-sessional tours. Of the guide booklets, Denmark was responsible for 6 , Finland 6 , Iceland 1, Norway 17 and Sweden 12. The seventy excursions covered an area between Iceland in the west and eastern Finland in the east, and between southern Denmark in the south and Spitsbergen in the north. The subjects covered by the various tours extended from recent volcanism and hot-spring activity in Iceland to Caledonian orogeny in Norway, from the Pre-Cambrian of Sweden and Finland to the Cretaceous and Tertiary sediments in Denmark.

The formal meeting of the Congress in Copenhagen was held under the patronage of H.M. King Frederik of Denmark. The first meeting of the Council was held on August 15. The opening of the General Assembly took place on August 16 in KB-hallen. Señor Garcia Rojas, president of the Twentieth International Geological Congress in Mexico first spoke; then the assembly was addressed by the Danish Prime Minister, Mr. Viggo Kempmann, and finally the newly elected president, Prof. Arne NoeNygaard, took the chair.

The following subjects had been selected for presentation and discussion, each subject corresponding to a section of the Congress : (1) geochemical cycles ; (2) geological results of applied geochemistry and geophysics; (3) Pre-Quaternary absolute age determination; (4) chronology and climatology of the Quaternary; (5) the Cretaceous-Tertiary boun- 
dary ; (6) Pre-Quaternary micropalæontology ; (7) Ordovician and Silurian stratigraphy and correlations; (8) Late Pre-Cambrian and Cambrian stratigraphy; (9) Pre-Cambrian stratigraphy and correlations ; (10) submarine geology; (11) regional and structural problems in oil geology; (12) regional palæogeography; (13) petrographic provinces, igneous and metamorphic rocks ; (14) the granite-gneiss problem; (15) genetic problems of uranium and thorium deposits ; (16) genetic problems of ores ; (17) minerals and the genesis of pegmatites ; (18) structure of the Earth's crust and deformation of rocks ; (19) Caledonian orogeny; (20) applied geology; (21) other subjects.

As a new feature in the arrangement of the meeting, it may be mentioned that all papers selected for presentation were printed prior to the sectional meetings and delivered to the participants on their arrival-more than 4,000 pages.

During the meeting, the following affiliated associa. tions and societies held meetings: International P'alæontological Union, Association of Sedimentary Geologists, International Association of Hydrogeologists, International Mineralogical Association, Association des Services Géologiques Africains, Society of Economic Geologists, International Commission for the Study of Clays. A joint symposium was arranged by the Geochemical Society and the Geochemical Commission of the International Union of I'ure and Applied Chemistry. The KarpatoBalkanic Association also held meetings.

The following commissions of the International Geological Congress held meetings and reported to the General Assembly on the business meeting of the Congress on August 23 : (a) International Commission on Stratigraphy, with several sub-commissions (Prof. R. C. Moore resigned, and a nominating committee for electing new officers was appointed with Dr. C. J. Stubblefield as chairman); the Commission to be continued. (b) Commission of the Geological Map of Europe (Prof. A. Benz and v. Gaertner); the Commission to be continued. (c) Commission of the Geological Map of the World, with two sub-commissions (Prof. M. F. Blondel); the Commission to be continued. (d) Commission on the Gondwana System (Dr. S. H. Haughton); it was suggested that this Commission be made a sub-commission to the Commission of Stratigraphy $(a)$ with four members, one from each of the following regions: South Africa, South America, Australia and India. (e) Commission on Meteorites (report by the secretary, Dr. M. H. Hey); Commission to be continued; Prof. E. L. Krinow was elected as the new president. ( $f$ ) Commission for the Formation of an International Geo- logical Abstracting Service (Dr. H. M. E. Sehürmann) : first number of a geological abstracting journal will be issued in the beginning of 1961 by Pergamon Press. (g) Commission de la Croûte Terrestre (Prof. C. E. Wegmann and Prof. P. Fourmarier); it was proposed that the existing Commission be discontinued and that its functions concerning the establishment of a lexicon of tectonic terms handed over to the sub-commission on the tectonic map of the world (under $c$ above) and that a new organization be formed under the title, "Commission de Coordination des Recherches Géologiques et Géophysiques", with Prof. J. Goguel as president. (h) Commission for the Spendiarov Prizo; members elected and functioning during the twenty-first session were the following: D. V. Nalivkin, J. M. Harrison, V. Marmo, M. Roubault and Th. Sorgenfrei.

During the meetings an exhibition of geological maps, instruments and books was arranged in an exhibition building near the main site of the Congress. The Mineralogical and Geological Museum of the University of Copenhagen, also situated near the main site, was open daily during the poriod; more than 3,000 visitors passed the main door during the. ten days.

At meetings of the Council of the Congress, traditional questions were treated in a traditional manner. Special treatment was given to the question of the formation of a Geological Union, which was prepared by the Bureau of the Congress before being presented to the Council for decision. The Council decided at its business meeting on August 23 to appoint an organizing committee for the formation of an International Geological Union. It was further decided that the organizing committee should prepart draft statutes of the Union in order to get it estab. lished in 1961. This committee consists of the following members: N. Belyaevsky (U.S.S.R.), W. Smulikowski (Poland), B. C. Roy (India), J. M. Harrison (Canada), T. B. Nolan (U.S.A.), L. Hawkes (United Kingdom), R. Laffitte (France), E. Clar' (Austria), H. M. E. Schürmann (Netherlands), K. A. Lindbergson (Sweden), V. Marmo (Finland), A. NoeNygaard (Denmark), J. A. Dons (Norway) and T. Sorgenfrei (Denmark).

At the closing meeting of the General Assembly on August 25, Dr. Sigurdur Thorarinsson, of Reykjavik. was awarded the Spendiarov Prize for his outstanding volcanological and tephrachronological studies in Iceland. Then representatives of former host cour. tries greeted the Congress, and Dr. Roy, from India. looked forward to seeing members in 1964, at the? twenty-second Congress, in his country.

ARNE NOE-NYGaARD

\section{POLLINATION BY INSECTS}

" $\mathrm{P}$ OLLINATION" was the subject of a symposium held during August 12-14 at Copenhagen prior to the eleventh International Congress of Entomology in Vienna. The symposium was presided over by Prof. Eric Åkerberg of the Swedish Seed Association, and the final sessions took place at the Association's plant breeding station at Svalöf.

The importance of bees as insect pollinators has long been recognized in the production of fruit and seeds of insect-pollinated plant species, and it was therefore natural that the majority of papers were concerned with bees. In the seed production of red clover, it was clear that humble bees wero useful pollinators in every country, but the value of honey bees varied from country to country. The special difficulties of obtaining satisfactory seed yields from tetraploid red clover, however, appeared to be due as much to abnormal pollen as to the lack of suitable pollinators.

Several speakers reported work on the habits of humble bees, and various attempts to increase the population of the humble bee were described. Danish 